\title{
KEPERCAYAAN DIRI DITINJAU DARI BODY IMAGE PADA SISWI KELAS X SMA
}

\author{
Ida Wati ${ }^{1}$, Sarinah ${ }^{2}$, Sri Hartini ${ }^{3}$ \\ Mahasiswa Universitas Prima Indonesia ${ }^{1}$, Dosen Universitas Prima Indonesia ${ }^{2}$, \\ Dosen Universitas Prima Indonesia ${ }^{3}$ \\ Jalan Sekip Sip. Sikambing, Medan \\ Sur-el: Idawati98yu@gmail.com ${ }^{1}$, Sarinahlumbantoruan@gmail.com², \\ Srihartini_Psikologi@unprimdn.ac.id ${ }^{3}$
}

\begin{abstract}
This study aims to determine the relationship between body image and selfconfidence. The hypothesis proposed in this study is that there is a positive correlation between body image and self-confidence with the assumption that the higher is body image, the higher will self-confidence be, and conversely the lower is body image, lower will self-confidence be. This research subjects were grade ten female students in a private school in Medan consisting of 125 students who were selected using purposive sampling technique. Data were obtained from a scale for measuring body image and self confidence. The calculation was performed through the prerequisite test analysis (assumption) that consisted of a test for normality and linearity. Data analysis used was Product Moment through SPSS 21 for Windows. The results of data analysis showed that $r=0,365$, and $p=0.000(p<0.05)$, indicating that there is a positive relationship between body image and self-confidence. The results of this study indicated that the contribution (R2) given variable of body image on self-confidence was 13.3 $\%$, while the remaining $87.7 \%$ was influenced by other factors not examined. From these results it is concluded that the hypothesis can be accepted.
\end{abstract}

Key word: Body Image, Self-Confidence, Ten Grade Female Students

Abstrak : Penelitian ini bertujuan untuk mengetahui hubungan antara body image dan kepercayaan diri. Hipotesis yang diajukan pada penelitian ini adalah "ada hubungan positif antara body image dan kepercayaan diri" dengan asumsi bahwa semakin tinggi body image maka semakin tinggi kepercayaan diri dan sebaliknya semakin rendah body image maka semakin rendah kepercayaan diri. Subjek penelitian yang digunakan dalam penelitian ini adalah siswi kelas X di salah satu SMA di kota Medan sebanyak 125 orang yang dipilih dengan menggunakan purposive sampling. Data diperoleh dari skala untuk mengukur body image dan kepercayaan diri. Perhitungan dilakukan melalui uji prasyarat analisis (uji asumsi) yang terdiri dari uji normalitas dan uji linearitas. Analisis data dengan menggunakan Analisa Product Moment melalui bantuan SPSS 21 for Windows. Hasil analisis data menunjukkan $r=0,365$, dan $\mathrm{p}=0.000(\mathrm{p}<0.05)$ yang menunjukkan bahwa ada hubungan positif ada body image dan kepercayaan diri. Hasil penelitian ini menunjukkan bahwa sumbangan $\left(\mathrm{R}^{2}\right)$ yang diberikan variabel body image terhadap kepercayaan diri adalah sebesar 13,3 persen, selebihnya 87,7 persen dipengaruhi oleh faktor lain yang tidak diteliti. Dari hasil penelitian ini dapat ditarik kesimpulan bahwa hipotesis yang diajukan dapat diterima.

Kata Kunci: Body Image, Kepercayaan Diri, Siswi Kelas X SMA

\section{PENDAHULUAN}

Remaja sering kali menilai dengan kritis tubuh mereka. Apakah tubuh mereka memiliki bentuk dan ukuran ideal. Secara sosial, remaja dianggap sebagai kelompok marginal, dan biasanya kelompok tersebut cenderung menunjukan keperluan yang besar akan konformitas kelompok. Media masa memanipulasi kecenderungan ini dengan 
menciptakan gambaran stereotip mengenai masa remaja yang menarik dan menyenangkan tanpa adanya jerawat, kawat gigi ataupun bentuk tubuh yang tidak proposional. Menurut Monks, Knoers, dan Hardinoto (2014) masa remaja dimulai dari usia 12 sampai 21 tahun, dengan pembagian 12 15 tahun adalah masa remaja awal, 15 - 18 tahun adalah masa pertengahan dan $18-21$ tahun adalah masa remaja akhir.

Masa remaja merupakan masa peralihan antara masa kanak-kanak dan dewasa yang mengalami masa pertumbuhan dan perkembangan pada fisik, kognitif, sosial dan emosional (Santrock, 2012). Pertumbuhan badan menjelang dan selama masa remaja ini menyebabkan tanggapan masyarakat yang berbeda pula. Mereka diharapkan dapat memenuhi tanggung jawab orang dewasa, tetapi berhubung antara pertumbuhan fisik dan pematangna psikisnya masih ada jarak yang cukup lebar, maka kegagalan yang sering dialami remaja dalam memenuhi tuntutan sosial ini menyebabkan frustasi dan konflik-konflik batin pada remaja terutama bila tidak ada pengertian pada pihak orang dewasa (Monks, dkk, 2014). Menurut Hurlock (Wiranatha \& Supriyadi, 2015) Salah satu faktor yang menyebabkan remaja yang dapat menerima keadaan tubuhnya dan menggunakannya dengan efektif adalah adanya kesadaran akan reaksi sosial terhadap berbagai bentuk tubuh yang membuat para remaja prihatin terhadap pertumbuhan tubuhnya yang tidak sesuai dengan standar budaya yang berlaku, munculnya jerawat dan gangguan kulit lainnya menjadi sumber kegelisahan para remaja, serta kecenderungan menjadi gemuk yang membuat sebagian remaja terganggu.

Menurut Santrock (Nurvita \& Handayani, 2015) Perhatian yang berlebihan pada bentuk tubuh yang sedang mengalami perubahan terutama sering terjadi selama pubertas pada masa remaja awal. Cash (Nurvita \& Handayani, 2015) mengungkapkan bahwa para remaja mengembangkan gambaran pribadi tentang bagaimana bentuk tubuh mereka dimana hal tersebut terkait erat dengan body image. Body image merupakan pengalaman individu yang berupa persepsi terhadap bentuk dan berat tubuhnya, serta perilaku yang mengarah pada evaluasi individu tersebut terhadap penampilan fisiknya.

Mueller (Santrock, 2012) menjelaskan bahwa body image merupakan sebuah aspek psikologis yang pasti terjadi, remaja sangat memperhatikan tubuhnya dan mengembangkan citra mengenai tubuhnya itu. Preokupasi terhadap citra tubuh sangat kuat diantara remaja, namun secara khusus sangat terlihat dimasa remaja awal, ketika remaja tidak puas dengan tubuhnya dibandingkan pada masa remaja akhir.

Thompson (Ridha, 2012) mengemukakan bahwa tingkat body image individu digambarkan oleh seberapa jauh individu merasa puas terhadap bagian-bagian tubuh dan penampilan fisik secara keseluruhan serta menambahkan tingkat penerimaan citra raga sebagian besar tergantung pada pengaruh sosial budaya yang terdiri dari empat aspek yaitu reaksi orang lain, perbandingan dengan orang lain, peranan individu dan identifikasi terhadap orang lain.

Jurnal Ilmiah PSYCHE Vol.13 No.1 Juli 2019: 1 - 12 
Menurut Bearman, dkk. (Santrock, 2012) terdapat perbedaan gender sehubungan dengan persepsi remaja mengenai tubuhnya. Secara umum, jika dibandingkan dengan anak laki-laki, anak perempuan lebih tidak puas dengan tubuhnya dan memiliki citra tubuh yang lebih negatif pada masa pubertasnya .Perubahanperubahan yang terjadi berakibat pada sikap dan perilaku remaja (Denich \& Ifdil, 2015). Hurlock (Ifdil, Denich, \& Ilyas, 2017) menjelaskan salah satu akibat perubahan ini adalah hilangnya kepercayaan diri. Anak remaja yang awalnya sangat yakin pada diri sendiri, menjadi kurang percaya diri dan takut pada kegagalan karena daya tahan fisik menurun dan karena kritik yang bertubi-tubi datang dari orang tua dan temantemannya (Denich \& Ifdil, 2015).

Kepercayaan diri menurut Goldsmith (2010) adalah kondisi dimana ketika seseorang mampu untuk keluar dari zona nyamannya, percaya akan kemampuan dirinya sendiri dan mampu untuk menikmati hidupnya dimana kepercayaan diri kepercayaan diri ini sudah ada di dalam hati dan jiwa masing- masing orang. Selain itu, menurut Dinnah (2006) kepercayaan diri adalah keyakinan pada diri sesorang mengenai apa yang harus dilakukan dan bagaimana cara melakukannya, individu yang percaya diri yakin terhadap hasil dari yang ia lakukan meskipun individu mendapat penolakan secara berulang ataupun tanpa adanya dukungan sosial individu akan tetap melakukan apa yang ingin mereka lakukan.

Kepercayaan diri menurut McGee (2010) adalah sebuah keyakinan adan kepercayaan akan kemampuan dan potensi diri sendiri dalam melakukan sesuatu meskipun individu belum pernah memiliki pengalaman untuk melakukan sesuatu sebelumnya. Kepercayaan diri akan memberikan anda kesempatan untuk melakukan hal-hal baru, menemukan tempat baru, menemukan talenta yang anda miliki, membuat individu merasa lebih baik mengenai dirinya dan memberikan perubahan yang positif untuk lingkungannya.

Menurut Lauster (Maulida \& Dhania, 2012) ciri-ciri orang yang mempunyai kepercayaan diri yaitu: (1) Percaya pada kemampuan sendiri. Kepercayaan atau keyakinan pada kemam-puan yang ada pada diri seseorang adalah salah satu sifat orang yang percaya diri. (2) Bertindak mandiri dalam mengambil ke-putusan. Dapat bertindak dalam mengambil keputusan terhadap diri yang dilakukan secara mandiri atau tanpa adanya keterlibatan orang lain dan mampu untuk meyakini tindakan yang diambil. (3) Memiliki rasa positif ter-hadap diri sendiri. Seseorang yang memiliki kepercayaan diri, jika mendapat kegagalan biasanya mereka tetap dapat meninjau kem-bali sisi positif dari kegagalan itu. (4) Berani mengungkapkan pendapat. Adanya suatu si-kap untuk mampu mengutarakan sesuatu dalam diri yang ingin diungkapkan kepada orang lain tanpa adanya paksaan atau rasa yang dapat menghambat pengungkapan tersebut.

Ifdil, Denich, dan Ilyas (2017) melalui penelitiannya pada 77 orang remaja putri di Kota Padang menemukan bahwa body image dengan kepercayaan diri memiliki hubungan yang signifikan. Siswa yang memiliki pandangan atau persepsi terhadap tubuh dan penampilannya yang positif maka kepercayaan dirinya tinggi, dan 
sebaliknya. Wirantha dan Supriyadi (2015) terhadap 492 remaja pelajar putri di kota Denpasar. Hasil penelitian dengan nilai $r=$ 0.350 dan $\mathrm{p}=0.000$ yang menunjukkan bahwa terdapat hubungan yang searah tetapi lemah antara citra tubuh dengan kepercayaan diri pada remaja pelajar puteri di kota Denpasar. Hubungan kedua variabel tersebut merupakan hubungan sebab akibat yaitu jika body image negatif maka kepercayaan dirinya juga rendah dan begitu sebaliknya.

Sehubungan dengan uraian diatas, penelitian ini memiliki tujuan untuk mengetahui pengaruh body image terhadap kepercayaan diri siswi kelas X SMA Methodist 2 Medan. Adapun hipotesis penelitian ini adalah terdapat hubungan positif antara body image dan kepercayaan diri pada siswi kelas X SMA dimana semakin positif body image maka semakin baik kepercayaan diri mereka.

\section{METODOLOGI PENELITIAN}

Subjek dalam penelitian ini adalah Siswi kelas X SMA Methodist 2 Medan yang berjumlah 125 siswi. Teknik pengambilan sampel yang digunakan dalam penelitian ini adalah teknik purposive sampling dengan karakteristik siswi dan berkisar usia 14-15 tahun. Purposive sampling yaitu teknik pengambilan sampel dengan pertimbangan tertentu (Sugiyono, 2013). Menurut Arikunto (2010) teknik ini dilakuan dengan cara mengambil subjek bukan didasarkan pada strata, random atau daerah tetapi didasarkan atas adanya tujuan tertentu. Teknik ini biasanya dilakukan karena ada beberapa pertimbangan, misalnya alasan keterbatasan waktu, tenaga dan dana sehingga tidak dapat mengambil sampel yang besar dan jauh.

Variabel dalam penelitian ini adalah body image sebagai variabel bebas dan kepercayaan diri sebagai variabel terikat.

Metode pengumpul data yang digunakan dalam penelitian ini adalah dengan menggunakan metode skala. Skala yang digunakan dalam penelitian ini adalah skala Likert, dimana skala Likert digunakan untuk mengukur sikap, pendapat, dan persepsi seseorang atau sekelompok orang tentang fenomena sosial. Dengan skala Likert, maka variabel yang akan diukur dijabarkan menjadi indikator variabel. Kemudian indikator atau aspek-aspek tersebut dijadikan titik tolak untuk menyusun aitem-aitem instrumen yang berupa pertanyaan atau pernyataan (Sugiyono, 2013). Skala Likert disajikan dalam bentuk pernyataan yang bersifat favourable dan unfavorable dengan empat alternatif jawaban untuk setiap butir pernyataan. Kriteria penilaian item favourable berdasarkan skala Likert dapat dijabarkan dengan angka dan kata sebagai berikut yaitu (1) untuk jawaban Sangat Tidak Setuju (STS), nilai (2) untuk jawaban Tidak Setuju (TS), nilai (3) untuk jawaban Setuju (S), dan nilai (4) untuk jawaban Sangat Setuju (SS). Sedangkan kriteria penilaian untuk item unfavourable adalah nilai (1) untuk jawaban Sangat Setuju (SS), nilai (2) untuk jawaban Setuju (S), nilai (3) untuk jawaban Tidak Setuju (TS), dan nilai (4) untuk jawaban Sangat Tidak Setuju (STS). Teknik pengumpulan data ini dilakukan dengan cara pembagian skala Jurnal Ilmiah PSYCHE Vol.13 No.1 Juli 2019 : 1 - 12 
(Sugiyono, 2013). Adapun empat pilihan jawaban dipakai dalam penyusunan skala ini adalah untuk menghindari kemungkinan jawaban di tengah-tengah. Subjek diminta untuk memilih salah satu dari keempat alternatif jawaban yang tersedia yang sesuai dengan keadaan subjek.

Pengumpulan data dalam penelitian ini menggunakan 2 skala yaitu Skala Kepercayaan Diri yang terdiri dari 34 butir aitem $(\alpha=0.912)$ yang disusun berdasarkan aspek-aspek kepercayaan diri yang diungkapkan Lauster (dalam Gufron \& Risnawati, 2016) yaitu: 1) Keyakinan kemampuan diri adalah sikap positif seseorang tentang dirinya sendiri. Ia mampu secara sungguh-sungguh akan apa yang dilakukannya 2)Optimis adalah sikap positif yang dimiliki sesorang yang selalu berpandangan baik dalam menghadapi dalam menghadapi segala hal tentang diri dan kemampuannya 3) Objektif yaitu Orang yang memandang permasalahan atau sesuatu sesuai dengan kebenaran semestinya, bukan menurut kebenaran pribadi atu menurut dirinya sendiri 4) Bertanggung jawab adalah kesedian orang untuk menanggung segala sesuatu yang telah menjadi konsekuensinya 5) Rasional dan realistis adalah analisis terhadap suatu masalah, sesuatu hal, dan suatu kejadian dengan menggunakan Skala Body image juga terdiri dengan 34 butir aitem $(\alpha=0.951)$ yang disusun berdasarkan dimensidimensi body image yaitu Cash dan Pruzinsky (2002), menjelaskan lima dimensi Body Image yaitu 1) Appearance evaluation (evaluasi penampilan), merupakan evaluasi penampilan dan keseluruhan tubuh. Evaluasi ini mencakup apakah individu menilai dirinya menarik atau tidak, serta apakah individu puas terhadap penampilannya atau tidak 2) Appearance orientation (orientasi penampilan), merupakan orientasi individu terhadap penampilannya dan usaha apa saja yang dilakukannya untuk mengubah penampilannya. Individu yang tingkat orientasi penampilannya rendah menunjukkan bahwa individu tidak berusaha untuk terlihat menarik dan penampilan bukan merupakan hal yang terlalu penting 3) Body area satisfaction (kepuasan terhadap bagian tubuh tertentu), merupakan kepuasan individu terhadap bagian tubuh tertentu, seperti wajah, rambut, tubuh bagian atas (bahu, lengan, dada), tubuh bagian tengah (punggung, pinggang, perut), tubuh bagian bawah (pinggul, bokong, paha, kaki), dan keseluruhan penampilan 4) Overweight preoccupation (kekhawatiran berkaitan dengan berat badan berlebih), merupakan kekhawatiran memiliki berat badan berlebih, kewaspadaan terhadap berat badannya, cenderung melakukan diet untuk mengurangi berat badan, dan membatasi pola makan 5) Self-classified weight (pengkategorian berat badan), merupakan bagaimana individu mengklasifikasikan dan mempersepsikan berat badannya dari rentang sangat kurus hingga sangat gemuk.

Validitas dan reliabilitas memegang peranan yang sangat penting dalam penelitian. Sebelum alat ukur tersebut dipakai, lebih dahulu harus diukur tingkat validitas setiap butir dan reliabilitas alat ukur. Validitas dan reliabilitas yang tinggi akan memberikan informasi yang baik mengenai keadaan subjek yang diteliti.

Menurut Sugiyono (2016), validitas adalah bila terdapat kesamaan antara data yang 
terkumpul dengan data yang sesungguhnya terjadi pada objek yang akan diteliti. Istilah valid memberikan pengertian bahwa alat ukur yang digunakan mampu memberikan nilai yang sesungguhnya dari apa yang diinginkan. Berdasarkan hasil try out, skala kepercayaan diri memiliki koefisien reliabilitas sebesar 0.912 dengan jumlah aitem yang valid sebanyak 34 butir dan hasil try-out skala body image menunjukkan koefisien reliabilitas sebesar 0.951 dengan aitem valid sebanyak 34 butir. Berdasarkan hasil koefisien reliabilitas tersebut, kedua skala yang digunakan untuk penelitian ini merupakan skala yang memiliki reliabilitas yang baik. harus Menurut Azwar (Hasmalawati \& Hasabati, 2017), suatu alat ukur akan memiliki koefisien reliabilitas yang tinggi apabila koefisien reliabilitasnya semakin mendekati angka 1.00 .

\section{HASIL DAN PEMBAHASAN}

Sebelum dilakukan pengujian Product Moment untuk melihat seberapa besar pengaruh body image terhadap kepercayaan diri, peneliti terlebih dahulu melakukan uji asumsi syarat yaitu uji normalitas dan uji linearitas. Uji normalitas terhadap data menunjukkan nilai Kolmogorov-Smirnov sebesar 0.979 dengan nilai signifikansi $\mathrm{p}=0.1465(\mathrm{p}>0.05)$ untuk variabel kepercayaan diri dan nilai Kolmogorov-Smirnov sebesar 0,595 dengan nilai signifikansi $\mathrm{p}=0.435$ dengan hasil yang menunjukkan bahwa $(\mathrm{p}>0.05)$ untuk variabel body image. Hasil tersebut menunjukkan bahwa kedua variabel memiliki distribusidata yang normal. Gambaran selengkapnya mengenai hasil uji normalitas pada data penelitian ini dapat dilihat pada tabel 1 berikut.

Tabel 1.

Uji Normalitas

\begin{tabular}{c|c|c|c}
\hline Variabel & Kolmogorov-Smirnov & $\mathbf{p}>\mathbf{0 . 0 5}$ & Bentuk \\
\hline Kepercayaan Diri & 0.979 & 0.1465 & normal \\
\hline Body image & 0.595 & 0.4355 & normal \\
\hline
\end{tabular}

Selain uji normalitas, juga dilakukan uji linearitas, dengan hasil yang menunjukkan bahwa hubungan antara variabel kepercayaan diri dan body image menghasilkan nilai koefisien $\mathrm{F}=20,167$ dengan nilai signifikansi $\mathrm{p}=0.000$. Hasil tersebut menunjukkan bahwa kedua variabel penelitian memiliki hubungan yang linear dan telah memenuhi syarat untuk dilakukan analisa korelasi Product Moment. Tabel 2 memberikan gambaran selengkapnya mengenai hasil uji linearitas pada data penelitian ini.

Tabel 2.

Uji Linearitas

\begin{tabular}{c|c|c|c}
\hline Variabel & Nilai $\mathbf{F}$ & Signifikansi $(\mathbf{p}>\mathbf{0 . 0 5})$ & Keterangan \\
\hline $\begin{array}{c}\text { Body image dengan } \\
\text { Kepercayaan Diri }\end{array}$ & 20.167 & 0.0000 & linear \\
\hline
\end{tabular}


Selain itu, pengujian skala kepercayaan diri menghasilkan mean empirik>mean hipotetik yaitu 88.9>85 sehingga dapat diartikan bahwa kepercayaan diri pada subjek lebih tinggi daripada populasi pada umumnya. Hal ini dapat dilihat dengan lebih jelas melalui tabel 3 .

Tabel 3

Perbandingan Data Empirik dan Hipotetik Kepercayaan Diri

\begin{tabular}{c|c|c|c|c|c|c|c|c}
\hline \multirow{2}{*}{ Variabel } & \multicolumn{3}{|c|}{ Empirik } & \multicolumn{3}{c|}{ SD } & \multicolumn{3}{c|}{ Hipotetik } & SD \\
\cline { 2 - 5 } & Min & Max & Mean & & Min & Max & Mean \\
\cline { 6 - 8 } & & & & & & & \\
\hline Kepercayaan diri & 59 & 111 & 88.94 & 11,070 & 44 & 136 & 85 & 17 \\
\hline
\end{tabular}

Selanjutnya diperoleh kategorisasi data kepercayaan diri dimana terdapat 6 subjek $(4,8 \%)$ yang memiliki kategori rendah, 109 subjek $(87,2 \%)$ yang memiliki kategori kepercayaan diri sedang, dan 10 subjek (8\%) yang memiliki kategori kepercayaan tinggi, sehingga dapat disimpulkan bahwa rata-rata subjek penelitian memiliki kepercayaan diri yang sedang. Gambaran yang lebih jelas dapat dilihat pada tabel 4 berikut ini.

Tabel 4

Kategorisasi Data Kepercayaan Diri

\begin{tabular}{c|c|c|c|c}
\hline Variabel & Rentang Nilai & Kategori & Jumlah (n) & Persentase \\
\hline \multirow{2}{*}{ Kepercayaan diri } & $\mathrm{x}<68$ & Rendah & 6 & $4,8 \%$ \\
\cline { 2 - 5 } & $68 \leq \mathrm{x} \leq 103$ & Sedang & 109 & $87,2 \%$ \\
\cline { 2 - 5 } & $\mathrm{x}>103$ & Tinggi & 10 & $8 \%$ \\
\hline \multicolumn{7}{c}{ Jumlah } & 125 & $100 \%$ \\
\hline
\end{tabular}

Hasil analisis skala body image menunjukan bahwa mean empirik<mean hipotetik yaitu $89,94<85$ dari data tersebut dapat diketahui bahwa body image pada subjek penelitian lebih rendah sedikit daripada populasi pada umumnya. Tabel 5 akan memberikan gambaran yang lebih jelas mengenai perbandingan data empirik dan hipotetik body image.

Tabel 5

Perbandingan Mean Empirik dan Hipotetik Body image

\begin{tabular}{c|c|c|c|c|c|c|c|c}
\hline \multirow{2}{*}{ Variabel } & \multicolumn{3}{|c|}{ Empirik } & \multicolumn{3}{|c|}{ SD } & \multicolumn{3}{|c|}{ Hipotetik } & SD \\
\cline { 2 - 3 } & Min & Max & Mean & & Min & Max & Mean & \\
\hline Body image & 37 & 124 & 84,94 & 16,331 & 34 & 136 & 85 & 17 \\
\hline
\end{tabular}

Setelah itu, diperoleh hasil kategorisasi data body image dimana terdapat 16 subjek (12,8\%) yang memiliki body image yang rendah, 94 subjek $(75,2 \%)$ memiliki body image sedang, dan 15 subjek (12\%) memiliki body image yg rendah. Berdasarkan penjelasan diatas dapat disimpulkan bahwa rata-rata subjek penelitian memiliki body image yg rendah. Data ini digambarkan dengan jelas melalu tabel 6 berikut. 
Tabel 6

Kategorisasi Data Body image

\begin{tabular}{c|c|c|c|c}
\hline Variabel & Rentang Nilai & $\begin{array}{c}\text { Kategor } \\
\text { i }\end{array}$ & $\begin{array}{c}\text { Jumlah } \\
(\mathbf{n})\end{array}$ & Persentase \\
\hline Body image & $\mathrm{x}<68$ & Rendah & 16 & $12,8 \%$ \\
\cline { 2 - 5 } & $68 \leq \mathrm{x} \leq 103$ & Sedang & 94 & $75,2 \%$ \\
\cline { 2 - 5 } & $\mathrm{x}>103$ & Tinggi & 15 & $12 \%$ \\
\hline \multicolumn{3}{c}{ Jumlah } & 125 & $100 \%$ \\
\hline
\end{tabular}

Setelah uji asumsi terpenuhi, maka selanjutnya dilakukan uji korelasi Product Moment untuk mengetahui seberapa besar pengaruh variabel bebas yaitu body image terhadap variabel terikat yaitu kepercayaan diri. Hasil analisis korelasi Product Moment menunjukan bahwa body image berpengaruh terhadap kepercayaan diri. Hal ini dapat dilihat dari nilai koefisin korelasi body image terhadap kepercayaan diri yaitu 0,365 dengan signifikansi $\mathrm{p}=0,000 \quad(\mathrm{p}<0,05)$. Koefisien korelasi dengan nilai positif menunjukan bahwa arah hubunngan yang positif antara body image dengan kepercayaan diri yaitu semakin positif body image maka semakinn baik kepercayaan diri dan begitu sebaliknya. Tingkat signifikansi korelasi sebesar $\mathrm{p}=0,0000(\mathrm{p}=0,05)$ menunjukan

bahwa terdapat hubungan yang signifikan antara body image dan kepercayaan diri. Sesuai dengan uraian diatas, dapat disimpulkan bahwa hipotesis penelitian yaitu adanya hubungan yang positif antar body image dan kepercayaan diri dapat diterima.

Nilai koefisien determinan ( $R$ Square) yang di peroleh adalah sebesar 0.133 menunjukan bahwa body image memberikan sumbangan efektif sebesar $13.3 \%$ pada kepercayaan diri. Sisanya sebesar $87,7 \%$ ditentukan atau dipengaruhi oleh variabel lain yang tidak diungkap dalam penelitian. Gambaran yang lebih jelas dapat dilihat pada tabel 7 .

Tabel 7.

Koefisien Korelasi Body image dengan Kepercayan Diri

\begin{tabular}{c|c|c|c|c}
\hline Model & $\boldsymbol{R}$ & $\boldsymbol{R}$ Square & Adjusted R Square & $\begin{array}{c}\text { Std. Error of the } \\
\text { Estimate }\end{array}$ \\
\hline Body image dengan Kepercayaan Diri & $0.365^{\mathrm{a}}$ & 0.133 & 0.126 & 10.3494 \\
\hline
\end{tabular}

enelitian ini menunjukan bahwa body image mempengaruhi kepercayaan diri siswi dimana terlihat bahwa semakin positif body image maka semakin baik kepercayaan diri pada siswi SMA kelas X Methodist 2 Medan. Pernyataan tersebut dibuat sesuai dengan hasil analisis koefisien korelasi sebesar 0,365 dengan signifikansi 0.000 $(p<0,05)$. Koefisien korelasi dengan nilai yang positif menunjukan bahwa arah hubungan antara body image dan kepercayaan diri adalah positif. Jurnal Ilmiah PSYCHE Vol.13 No.1 Juli 2019: 1 - 12 
Tingkat signifikansi sebesar $\mathrm{p}=0,000$ menunjukan bahwa adanya hubungan yang signifikan antara body image dan kepercayaan diri pada siswi SMA kelas X Methodist 2 Medan

Penelitian ini sesuai dengan penelitian terdahulu yang dilakukan oleh Wiranatha dan Supriyadi (2015) terhadap 492 siswi dari lima SMAN Denpasar. Hasil penelitian mereka menunjukan adanya hubungan yang searah tetapi lemah antara body image dan kepercayaan diri pada remaja pelajar putri di Kota Denpasar. Andiyati (2016) juga melakukan penelitian mengenai hubungan antara body image dan kepercayaan diri pada 142 siswa kelas X di SMA Negeri 2 Bantul yang hasilnya menunjukan adanya hubungan positif yang sangat signifikan antara body image dan kepercayaan diri siswa kelas X SMA Negeri 2 Bantul.

Berdasarkan hasil analisis yang telah dilakukan, dapat dikatakan bahwa mayoritas siswi kelas X SMA swasta Methodist 2 Medan memiliki body image dan kepercayaan diri dalam kategori sedang. Hal ini mendeskripsikan bahwa banyak siswi yang memiliki penilaian dan pandangan yang yang tidak begitu positif. Kebanyakan dari mereka cenderung kurang puas dengan bentuk fisik yang mereka, rasa minder dan ingin mencoba memperbaiki fisik dan penampilan mereka sangat sering mereka rasakan. Mereka juga cenderung suka meminta bantuan dari orang lain dalam melakukan sesuatu. Menurut Rombe (2014) body image merupakan suatu sikap atau perasaaan puas dan tidak puas yang dimiliki seseorang atau suatu individu tertentu terhadap tubuhnya sehingga dapat melahirkan suatu penilaian yang positif atau negatid pada dirinya tersebut. Seperti yang diungkapkan oleh Melliana (Andiyati, 2016) remaja yang memiliki pandangan negatif terhadap fisiknya akan menjadi resah, memiliki pikiran dan perasaan yang negatif dalam menilai tubuhnya atau kondisi fisiknya. Berbeda halnya dengan remaja yang memiliki pandangan yang positif terhadap fisiknya, remaja yang menilai fisiknya sendiri secara positif, secara keseluruhan remaja tersebut akan merasa nyaman dan percaya diri.

Berdasarkan penjelasan diatas dapat kita lihat bahwa body image memiliki hubungan dengan kepercayaan diri, dapat diasumsikan bahwa kepercayaan diri adalah salah satu aspek kepribadian yang penting pada seseorang. Tanpa adanya kepercayaan diri akan banyak menimbulkan masalah pada diri sesorang. Kepercayaan diri merupakan atribut yang paling berharga pada diri seseorang dalam kehidupan bermasyrakat. Dikarenakan dengan kepercayaan diriseseorang mampu mengaktualisasikan segala potensi dirinya (Gufron \& Risnawati, 2016). Menurut Burton dan Platts (2006) kepercayaan diri adalah kemampuan untuk melakukan sesuatu dengan benar dan tepat dalam kehidupannya sehari-hari tidak peduli seberapa besar tantangan yang sedang dihadapi. Seperti halnya menurut Bandura (dalam Hurlock, 1980) kepercayaan diri adalah suatu keyakinan seseorang untuk mampu berperilaku sesuai dengan harapan dan keinginann.

Menurut Hendra Surya (Rahayuningyah, 2016) Percaya diri adalah sebagai cara pandang seseorang atau gambaran pemikiran dan perasan keyakinan, kesanggupan maupun keberanian 
seseorang terhadap segenap aspek kemampuan yang dimilikinya. Aspek kemampuan tersebut, meliputi kemampuan intelektual, sikap, peasaan, kekuatan fisik, dan penampilan diri. Fereira (Nasution, 2009) seorang konsultan dari Deloitte and Touche Consulting mengatakan bahwa seseorang yang memiliki kepercayaan diri, di samping mampu mengendalikan dan menjaga keyakinan dirinya, juga akan mampu membuat perubahan di lingkungannya, ini berarti bahwa kepercayaan diri akan mempengaruhi pengenalan diri, pengendalian diri, motivasi, empati dan keterampilan sosial. Nasution (2009) berpendapat bahwa rasa percaya diri yang kuat sebenarnya hanya merujuk pada adanya beberapa aspek dari kehidupan individu tersebut dimana ia merasa memiliki kompetensi, yakin, mampu dan percaya bahwa dia bisa, karena didukung oleh pengalaman, potensi aktual, prestasi serta harapan yang realistik terhadap diri sendiri. Bagi mereka yang kurang percaya diri, setiap kegagalan mempertegas rasa tidak mampu mereka. Tidak adanya percaya diri dapat mewujud dalam bentuk rasa putus asa, rasa tidak berdaya, dan meningkatkan keraguan kepada diri sendiri.

Remaja yang memiliki padangan yang positif mengenai bentuk dan ukuran tubuh mereka cenderung memiliki kepercayaan diri yang baik. Sebaliknya remaja yang memiliki pandangan yang negatif terhadap tubuh mereka cenderung memiliki kepercayaan diri yang rendah.Remaja yang merasa tidak puas dengan bentuk tubuhnya, seperti lengan atau paha yang terlalu besar, bentuk tubuh yang kurang ideal merupakan salah satu tanda bahwa remaja mulai memiliki body image yang negatif terhadap tubuhnya sendiri.

Hurlock (1980) mengemukakan Salah satu faktor yang menyebabkan remaja yang dapat menerima keadaan tubuhnya dan menggunakannya dengan efektif adalah adanya kesadaran akan reaksi sosial terhadap berbagai bentuk tubuh yang membuat para remaja prihatin terhadap pertumbuhan tubuhnya yang tidak sesuai dengan standar budaya yang berlaku, munculnya jerawat dan gangguan kulit lainnya menjadi sumber kegelisahan para remaja, serta kecenderungan menjadi gemuk yang membuat sebagian remaja terganggu.

Penelitian ini memiliki beberapa keterbatasan yaitu dikarenakan pembagian kuisioner yang dilakukan dengan memohon waktu luang disaat jam pelajaran atau ketika jam pelajaran akan dimulai. beberapa partisipan mungkin menjawab kuisioner tersebut dengan terburu-buru karena akan melanjutkan pelajaran, sehingga kurang akurat dalam mengukur beberapa keadaan diri partisipan yang sebenarnya.

Berdasarkan hasil analisis data menunjukan body image memberikan sumbangan efektif sebesar 13,3\% terhadap kepercayaan diri. Selebihnya $86,7 \%$ dipengaruhi oleh faktor-faktor lainnya.

\section{SIMPULAN}

Berdasarkan hasil penelitian, dapat disimpulkan bahwa hipotesis penelitian yaitu adanya hubungan positif antara body image dan Jurnal Ilmiah PSYCHE Vol.13 No.1 Juli 2019: 1 - 12 
kepercayaan diri pada siswi kelas X SMA Swasta Methodist 2 Medan dapat diterima. Terdapat beberapa saran untuk para remaja putri yaitu agar remaja putri dapat menggali kemampuan diri agar bisa berprestasi yang pada akhirnya bisa meningkatkan kepercayaan diri remaja agar dapat bersikap positif dan menerima semua hal dengan sebagaimana adanya dan tidak hanya berfokus terhadap kualitas fisik saja. Bagi peneliti selanjutnya diharapkan dapat mencari faktor lain seperti dukungan sosial dan obesitas yang dapat mempengaruhi kepercayaan diri.

\section{DAFTAR RUJUKAN}

Andiyanti, A. D. W . (2016). Hubungan Antara Body image dengan Kepercayaan Diri Siswa Kelas $X$ di SMA Negeri 2 Bantul. E-Journal Bimbingan dan Konseling Edisi 4 tahun ke-4, 80-8. Diambil dari: http://eprints.uny.ac.id/33583

Arikunto, S. (2010). Prosedur Penelitian: Suatu Pendekatan Praktik. Jakarta: PT.Rineka Cipta

Burton, K \& Platts, B. (2006). Building Confidence for Dummies. England: John Wiley \& Sons, LTD. Diambil dari: https: / / ixz.es/Building\%20Confidence\%20for $\% 2$ ODummies.pdf

Cash, T F \& Pruzinsky, T. (2002). Body Image_A Handbook of Theory, Research, and Clinical Practice. New York: The Guilford Press. Diambil dari: $\underline{\text { http://b- }}$ ok.xyz/book/1069130/9f952d

Denich, A. U., \& Ifdil. (2016). Konsep Kepercayaan Diri Remaja Putri. Jurnal Pendidikan Indonesia, 2(2), 43-52. Diambil dari: http://journal2.um.ac.id/index.php/jkbk/article/ view/1267/pdf

Dinnah, M. (2006). Coming Out Asperger: Diagnosis, Disclosure, and Self-Confidence. London: Jessica Kingsley Publishers. Diakses pada tanggal 60 maret 2018 dari: http://okezone.co.uk/document/smallbusiness-phonesystems.pdf\#Y29taW5nLW91dC1hc3Blcmd lci1kaWFnbm9zaXMtZGlzY2xvc3VyZS1h bmQtc2VsZi1jb25maWRlbmN1LnBkZg==

Goldsmith, Barton. (2010). 100 Ways to Boost Your Self-Confidence: Believe in yourself and others will too. U.S.A: The Career Press. Diambil dari:

https://www.google.com/url?sa=t\&rct=j\&q $=\&$ esrc $=$ s\&source $=$ web $\& c d=1 \& c a d=$ rja $\& u a$ $\mathrm{ct}=8 \& \mathrm{ved}=2$ ahUKEwiXhY35hMbcAhXX Md4KHUW1CZEQFjAAegQIABAC\&url= http $\% 3 \mathrm{~A} \% 2 \mathrm{~F} \% 2 \mathrm{Fmindguruindia.com} \% 2 \mathrm{FW}$ p-

content $\% 2$ Fuploads $\% 2 F 2014 \% 2 F 06 \% 2 F M P$ 016_100_Ways_to_Boost_Your_Self_Confid ence OnlyGill.pdf\&usg=AOvVaw0BAp8d3 JofKWMvXzizPSIK

Gufron, M., N., \& Risnawita S., R. (2016). Teoriteori Psikologi. Yogyakarta: Ar Ruzz M 
Hasmalawati, N., \& Hasanti, N. (2017). Pengaruh Kualitas Kehidupan Kerja dan Motivasi Kinerja Karyawan. MEDIAPSI, 3(2), 1-9. Diambil dari: https://mediapsi.ub.ac.id/index.php/mediapsi/ar ticle/view/61

Hurlock, E., B. (1980). Psikologi Perkembangan: Suatu Pendekatan Sepanjang Rentang Kehidupan Edisi Kelima. Jakarta: Penerbit Erlangga

Ifdil, I., Denich, A. U., \& Ilyas, A. (2017). Hubungan Body image dan Kepercayaan Diri Remaja Putri. Padang: Jurnal Kajian Bimbingan dan Konseling. 2(3), 107-113. Diambil dari: http://journal2.um.ac.id/index.php/jkbk/article/ view/1267/pdf

Maulida, S,, R., \& Dhania, D., R. (2012). Hubungan Kepercayaan Diri dan Dukungan Orang Tua dengan Motivasi Berwirausaha pada Siswa SMK. Jurnal Psikologi UNDIP. 11(2), 1-8. Diambil dari: https://ejournal.undip.ac.id/index.php/psik ologi/article/view/6630

McGee, P. (2010). Self-Confidence: The Remarkable Truth of Why a Small Change Can Make a Big Difference. Chichester: Capstone Publishing, Ltd. Diambil dari: https://www.google.com/url?sa=t\&rct=j\&q $=\&$ esrc $=$ s\&source $=$ web\&cd $=7 \& \mathrm{cad}=$ rja $\& u a$ $\mathrm{ct}=8 \&$ ved=2ahUKEwifzquihsbcAhWUM94 KHYN_AhwQFjAGegQIBhAC\&url=http $\%$ 3A\%2F\%2Fftp.opencast.org\%2F6041e2tis 17 7\%2F05-mohammad-crooks3\%2F9781531818555-self-confidence-theremarkable-truth-of-why-a-smoGAaRKnbidm.pdf\&usg=AOvVaw1frUtTj gHuQwzRK-mC8aIA

Monks, F., J., Knoers, A. M. P., \& Hadinoto, S., R. (2014). Psikologi Perkembangan: Pengantar dalam Berbagai Bagiannya. Yogyakarta: Gadjah Mada University Press

Nasution, F. A. (2009). Pengaruh Kecerdasan Emosional dan Kepercayaan Diri Terhadap Tingkat Pemahaman Akuntansi Mahasiswa UMSU. Jurnal Riset Akuntansi dan Bisnis, 9(2), 111-122. Diambil dari: http://jurnal.umsu.ac.id/index.php/akuntan/arti cle/view/462
Nurvita, V., dan Handayani, M. M. (2015). Hubungan antara Self-Esteem dengan Body image pada Remaja Awal yang Mengalami Obesitas. Jurnal Psikologi dan Kesehatan Mental, 4(1), 41-19. Diambil dari: http://www.e-jurnal.com/2015/09/hubunganaantara-self-esteem-dengan.html

Rahayuningdyah, Endah. (2016). Upaya Meningkatkan Kepercayaan Diri Melalui Layanan Konseling Kelompok Pada Siswa Kelas VIII D di SMP Negeri 3 Ngrambe. JIPE, 1(2), 1-14. Diambil dari: http://jurnal.stkipngawi.ac.id/index.php/JIPE/ar ticle/view/155

Ridha, Muhammad. (2012). Hubungan antara Body image dengan Penerimaan Diri pada Mahasiswa Aceh di Yogyakarta. Jurnal EMPHATY, 1(1), 111-121. Diambil dari: http://www.jogjapress.com/index.php/EMPAT $\mathrm{HY} /$ article/view/1419

Rombe, Sufrihana. (2014). Hubungan Body image dan Kepercayaan Diri dengan Prilaku Konsumtif pada Remaja Putri di SMA Negeri 5 Samarinda. EJournal Psikologi, 2(1) , 76-91. Diambil dari: http://ejournal.psikologi.fisipunmul.ac.id/site/?p=722

Sugiyono. 2013. Metode Penelitian Manajemen. Bandung: Penerbit Alfabeta.

Sugiyono. 2016. Metode Penelitian Kuantitatif, Kualitatif, dan R\&D. Bandung: Alfabeta

Wiranatha, F. W., \& Supriyadi. 2015. Hubungan antara Citra Tubuh dengan Kepercayaan Diri Pada Remaja Pelajar Putri di Kota Denpasar: Jurnal Psikologi Udayana, 2(1), 38-47. Diambil dari: https://ojs.unud.ac.id/index.php/psikologi/articl e/view/25139

Santrock, J. W. (2012). Life Span Development : Perkembangan Masa-Hidup Edisi Ketigabelas Jilid 1. Jakarta: Penerbit Erlangga. 